\title{
Analysis of the Factors for the Strengthening of the Indonesian Traditional Market
}

\author{
Sri Suwitri and Sri Indarti \\ Public Administration Doctoral Program, Faculty of Social and Political Science \\ Diponegoro University \\ Semarang, Indonesia \\ (Office Email: prodidap@gmail.com)
}

\begin{abstract}
The traditional market is heavily developed by the Indonesian Government in the last two decades, where as one of the underpinning national economy, it is improved hold many labor, a main container product sales - products of people's economy. As the traditional market of public space has local identity that strengthens national identity, which requires strengthening in order to awake functions and its society role, the region and nation. Some policies have been implemented by the Government, such as revitalizing and coaching. In conjunction relates this strengthening traditional markets necessity so it can grow and optimally beneficial. This research analyzes the strengthening traditional markets factors in Indonesia, with a case study on Pasar Gede in Solo and Panorama market in Bengkulu. The findings that gain factors strengthening the traditional market is the local identity strengthening, strengthening governance, the physical strengthening, the society participation strengthening, as well as local interaction patterns strengthening.
\end{abstract}

Keywords_Traditional Market; Government; Region

\section{INTRODUCTION}

The traditional market is public space becomes the identity of an area and usually have the own characteristic. The traditional market is a market which is considered successful by the economic and social activity, marked by providing comfortable spaces, accessible, and socio-cultural activity into containers contributes optimal both for traders, buyers, communities or regions. Traditional market development program has been implemented in various regions of the city in the last decade. This is an encouraging innovation in the market management, where some of the hopes pinned by many parties that this development will provide increased functionality of the traditional market for merchants, communities and regions.

With respect to the existence of the phenomenon, the required strengthening of the traditional market, where revitalization not only deals with the physical aspect, but also the reinforcement on the other factors, as the subject of trader capacity to strengthen wheels, useful activities is optimal for the community and the region as well as to develop people's economy.

\section{A. The Identity of Pasar Gede and Panorama Traditional} Market

\section{1) Pasar gede Traditional Market}

Pasar gede has a local identity, including special food, crafts and local products that reflect local wisdom and local identity Solo. Local food specialties of Pasar Gede Solo (Suwitri, 2014), namely:"Dawet telasih , Brem, jaddah blondo, Sambal wijen, Moto maling /kulit mlinjo, Rabuk rambak yang terdiri dari ketupat kelapa dan wijen”o.

Then at pasar Gede there are also food which is a local identity in some areas of Central Java and a chance to national identity. "Local Identity that could potentially become a national identity at the Pasar Gede is Intip manis dan intip asin, Kripik ceker, paru, usus, dan tembolok ayam (they became typical also for the area of the County and the city of Magelang), Lenjongan (jajan pasar consists of Gatot, tiwul, klepon, cetil, lopis). In other areas in Java called jajan pasar. Currently in Indonesia and Malaysia market began to be sold in mall food courts, supermarkets, restaurants and hotels of international class. The identity of the other is jaddah pisang (in Semarang city called getuk pisang), Nggarut (sold in traditional markets in Central Java), Sambal pecel (many sold in traditional markets and malls in the whole of Indonesia), Serundeng (being typical in the rest of Central Java), Krupuk Karak and Krupuk Kulit Kerbau is also a typical food all over Indonesia, Sayur Cenil (in other areas called watercress, commonly used for fresh vegetables, in the Wonosobo Regency used for vegetable salad), Kopi Angkringan (in other areas called Sego Kucing), Garam Krasak, Lulur Rempah, Bedak Jebuk Sari for acne, Grabah/kitchen utensils from wood, Batik Lurik, DaunJati Cina herbal slimming as a very popular female Solo to always awake their sliming (Suwitri, 2014)

Interaction pattern language, culture and local identity is being developed into a national identity. The pattern of these interactions occur between managers, among managers with traders, the interaction between the trader and the buyer and the interaction between the Manager of the market, traders and buyers. Suwitri, 2014). The identity of the local interaction of Pasar Gede can be observed from the interaction between ethnicity and acculturation between Chinese and Javanese ethnic, like the celebration of Chinese new year accompanied the growth of Sudirowajan grebeg with the appearance of the lion dance, which has become an annual agenda in Pasar Gede 
as the market has a close relationship with the ethnic Chinese, where many residents of Chinese descent who have been trading in Pasar Gede since a decades ago.

\section{2) Panorama Market}

Market Panorama is the largest traditional market in Bengkulu city, which in addition to standard market stall management, los and sellers, also hosts of Pasar Subuh and Pasar Sore. These markets are more provision of the results of the Earth, the sea and the community product such as various types of fish, crabs, lokan, assorted vegetables and fruit. Pasar Subuh Panorama is also enjoyed with variegated traditional cakes and food service markets. Need to Setup street vendors with the use of roads and parking lots at the time of Pasar Subuh and Pasar Sore celebration. Trade and Market bustle, Pasar Subuh Panorama has increased since the year 2013, with the dissolution from Pasar Subuh to Pasar Minggu, so the majority seller moved to the Barukoto Market and Panorama market.

Typical foods that are present in Panorama market Bengkulu is pendhap, tempoyak, lempuk (dodol durian), kripik beledang, bagar hiu, lemang bambu (glutinous rice in bamboo, eaten with sticky black tape), tat Pastry, and kalamansi syrup. Then there are craft products typical Besurek Batik from Bengkulu (batik motif calligraphy) and souvenirs from lantung skin.

Fishing product, the results of the Bengkulu community in Panorama market, such as mussels, snails, live fish (shrimp/crab, estuary life), Lokan (kind of snail shells animals with flat forms, living at the bottom of the river), Kemukus (small fish in the sea mix make vegetable fritter). Most of these products are mostly held in the morning and afternoon Panorama market. Other products that are typical of communities such as agate variety such as Bengkulu red rafflesia, citrus kalamansi used to mix dishes and making syrup (see in Indarti, 2015).

Traders in Panorama market consists of many different ethnicities such as Padang, Bengkulu, Java, Pekal, Lembak, Selatan, Rejang, Serawai, Pekal. There is local wisdom for mutual cooperation and mutual activity in the market as there are cooperatives and associations which support social gathering interaction and trade activities.

\section{Theoretical Framework And Method}

Strengthening Factors of Traditional Markets need to be Developed in Indonesia, as follows:

\section{A. Strengthening the local identity to strengthen nationalism}

National identity are preserved in fact describe the love and pride for the community in culture. Nationalism as a form of love of society against the nation's culture can be seen in a traditional market. The cultural condition in an area is the local identity. Local identity is turning to support a national identity (Suwitri, 2014).

The identity of the local traditional market need to be strengthened, for example by organizing or delivering special to los existing traditional food such as in pasar gede, or panorama. So too would be good provided the special souvenirs from Lantung skin and bati besurek at the Panorama so that batik is more popular and increasingly spurred innovation, style and design motifs. Local wisdom that exists in each of the traditional market is also care and developed, like mutual merchant associations and cooperatives, as well as traditional suggestion in selling.

\section{B. Governance Strengthening}

Governance towards traditional markets need to be optimized by traditional market manager, by optimizing the interests of traders, tourists and the direction of the traditional market development strategy in the future (Indarti, 2015). The management of the market need to have traditional market forces direction setting each one in the future, for example the development of typical local foods, or certain fabrics or other local wisdom, where it became the distinctive advantages of each market as well as excellence compared to modern market that often develop special services.

Governance the kiosk owner, sellers and sellers requires its own strategy and technical operation accordance with the conditions and needs of the market and society.

\section{The Physical Market Strengthening}

There are still many loyal visitors at traditional markets because there are certain items that can only be found at traditional markets, a strategic location, reasonable price or the appropriate interaction pattern (Indarti, 2015. This phenomenon needs to be accompanied by a strengthening of the physical market, managers need to devise strategies and make improvements or physical strengthening gradually, such as cleanliness, comfort, handling, waste traders Setup optimally.

Strengthening this can reduce physical phenomena were middle-to upper-society are turning looking for an alternative to spending four others such as street vendors surrounding the existing market, or switch to modern store such as supermarkets, mini markets, supermarkets are usually concerned with cleanliness and comfort. The role of Manager is mainly from the Government apparatus have an important position to devise strategies and develop physical strengthening traditional markets.

\section{RESULT AND DisCUSSION}

\section{A. Strengthening of Community Participation}

The participation of merchants and the community need to be developed in decision making and policy setting of the market, where they better understand local needs and conditions. So the market changes and the empowerment of the Community market, directed in accordance with the interests of the traders and the community.

\section{B. Strengthening of Local Interaction Patterns}

Interaction pattern language, culture and local identity is being developed into a national identity. The pattern of these interactions occur between managers, among managers with traders, the interaction between the trader and the buyer and the 
interaction between the Manager of the market, traders and buyers. The interaction-interaction gave rise to local identity (Suwitri,2014). With regard to this need strengthening traditional markets by supporting and developing local interaction patterns came back positive, like togetherness, egalitarian atmosphere, mutual and synergy between different ethnic and culture that already exist in the traditional market.

\section{CONCLUSION}

Pasar Gede and Panorama traditional market has a local identity, in the form of food products and the results of the local community, as well as the identity of the local interaction. Factors strengthening traditional markets include strengthening of local identity, strengthening governance, the strengthening of physical participation, strengthening and reinforcement of local interaction patterns.

\section{REFERENCES}

[1] Suwitri, Sri, 2014, Policy Of Nationalism Guidance Through In Traditional Market Management In Central Java, International Journal of Research in Commerce, IT \&amp;Management: Vol..No. 4 (2014) ISSUE No. 08 (AUGUST) ISSN 2231-5756. Publishedby IJRCM : India

[2] Indarti, Sri, 2015,Pengembangan Manajemen Komunitas pada Pasar Panorama sebagai Pasar Tradisional Percontohan di Kota Bengkulu. makalah FKSP UMB 